\title{
GㄷNI도
}

\section{RESIDUAL TLC SILICA GEL: RECUPERATION PROCESS, CHARACTERIZATION AND APPLICATION.}

\section{SÍLICA GEL CCD RESIDUAL: PROCESSO DE RECUPERAÇÃO, CARACTERIZAÇÃ̃o E APLICAÇÃO.}

Juciely Carvalho Maia ${ }^{1}$; Francisco Samuel da Cunha Lima Batista ${ }^{2}$; Diógenes Gaudêncio da Silva Fernandes $^{3}$; Maria Alexsandra de Sousa Rios ${ }^{4}$

${ }^{1}$ Mestrado em Desenvolvimento e Meio Ambiente - MDMA

Universidade Federal do Piauí - UFPI - Teresina/Piauí - Brasil

juciely.grintequi@gmail.com

${ }^{2}$ Grupo de Inovações Tecnológicas e Especialidades Químicas - GRINTEQUI

Universidade Federal do Piauí - UFPI - Teresina/Piauí - Brasil

samuel.grintequi@gmail.com

${ }^{3}$ Grupo de Inovações Tecnológicas e Especialidades Químicas - GRINTEQUI

Universidade Federal do Piauí - UFPI - Teresina/Piauí - Brasil

diogenes.grintequi@gmail.com

${ }^{4}$ Departamento de Engenharia Mecânica - DEM

Universidade Federal do Ceará - UFC - Fortaleza/CE - Brasil

alexsandrarios@ufc.br

\begin{abstract}
Resumo
A utilização de sílica gel de forma intensiva em laboratórios químicos tem um custo elevado, e gera uma quantidade significativa de resíduos sólidos contaminados com compostos orgânicos. Nesse sentido, a busca de métodos eficazes para reduzir os impactos que este material pode causar ao meio ambiente, tem sido um fator de motivação para muitos pesquisadores, uma vez que a sua utilização tem crescido bastante no segmento de pesquisa científica. Assim, o presente trabalho apresenta o processo de recuperação, caracterização e aplicação do gel de sílica 60G, um adsorvente usado na preparação de Cromatografia de Camada Fina. De acordo com os resultados, o método proposto foi capaz de recuperar o gel de sílica residual, tornando-se possível, para ser reutilizado no processo de separação elou purificação de compostos orgânicos de um modo prático e com um impacto ambiental reduzido.
\end{abstract}

Palavras-chave: química verde; cardanol hidrogenadosílica gel; cardanol alquilado.

\section{Abstract}

The use of silica gel intensively in chemical laboratories has a high cost, and generate a significant amount of solid waste contaminated with organic compounds. In this sense, the search for effective 
methods to reduce the impacts that this material can cause to the environment, has been a motivating factor for many researchers, since its use has grown extensively in scientific research segment. So, the present work shows the recuperation process, characterization and application of the Silica Gel 60G, a adsorbent used in the preparation of Thin Layer Chromatography. According to the results, the proposed methodology was able to recover the residual silica gel, making it possible to be reused in the process of separation and/or purification of organic substances in a practical manner and with reduced environmental impact.

Keywords: green chemistry, hydrogenated cardanol silica gel, alkylated cardanol.

\section{Introduction}

The way chemical analyzes and waste chemicals should be handled were taken into consideration in the 1990's as a consequence of the arising of a new trend that started the concern about the impact of such practices in the environment [1,2,3]. This emerging area which aims to protect the environment and the human health is known as: 'Green Chemistry', 'Clean Chemistry', 'Environmentally Benign Chemistry' or 'Benign- by- Design Chemistry'.

This new branch of science embodies a new approach to the synthesis, processing and application of chemical substances that are designed to reduce threats to health and the environment by decreasing or eliminating pollution. It incorporates 12 principles that contribute to the development of a New Green Chemistry Industry, attain sustainable development and prioritize environmentally friendly chemical activity [4-9].

Considering the above, the waste generated in educational and research institutions have been promoting a great concern since they are an environmental and social issue, due to their constant increase and poor storage conditions. This situation gets even worse if we consider the growing number of research groups, laboratories and educational and research centers that contribute to the increase of such residues, which are: chemical, biological and radioactive [10].

Among the residues arising from the activities of teaching and research in the chemical segment, silica gel occupies a prominent place, since it is widely used in experimental procedures involving lines of research in organic chemistry, natural products chemistry, as well as in chemical development of new products.

Among the various applications of this adsorbent, it can be highlighted its use as a stationary phase in separation operations [11,12], used in experimental procedures for isolation and purification of organic compounds of low and medium polarity, which can be natural or synthetic $[12,13]$. In this context, this adsorbent is widely used in chemistry pharmacy and biology laboratories and is essential for the development of researches who work with natural products and new molecules synthesis.

The use of silica gel intensively in these laboratories has a high cost, and generate a significant amount of solid waste contaminated with organic compounds [10]. In this sense, the 
search for effective methods to reduce the impacts that this material can cause to the environment, has been a motivating factor for many researchers, since its use has grown extensively in scientific research segment [14].

According to the literature, there are various techniques to recover column chromatography silica gel $[10,14,15,16]$. However, it does not discuss any method related to the recovery of thin layer chromatography (TLC) silica gel. Due to the remarkable evidence of waste generation after using this adsorbent, the present paper presents a methodology to recover Silica Gel 60G (used in the preparation of TLC) with low operating cost and simple experimental procedure comprising the technological development grounded in sustainability.

In the research branch of adsorbents recovery it is important to note that since 2011, the Technology Innovations and Specialty Chemicals Group (GRINTEQUI) have been working on the recovery and reuse of TLC and column chromatography (CC) silica gel. The residual silica used for the treatment was given by the local laboratories: GRINTEQUI Laboratory - from Federal University of Ceará and Natural Products Laboratory (LPN) - from Federal University of Piauí.

With the recovery of these materials it is intended to meet the principles of Green Chemistry regarding the risks to human health and the environment by minimizing waste generation in chemical laboratories. Added to this, the silica is a very important material for the above areas and their recovery and reuse cause environmental gains and cost reduction in the development of projects in the field of organic chemistry and related sciences.

\section{Experimental procedures}

\subsection{Material}

The present work applied silica gel 60G (Vetec $®)$ with particle size ranging between 5 and 40 micrometers. It was used sodium hypochlorite $(2.5 \%, \mathrm{w} / \mathrm{w})$ and distilled water for the treatment of residual TLC silica gel.

Reagent sodium hypochlorite was purchased from commercial suppliers and solvent hexane from Synth®. Both were used without further purification.

\subsection{Equipaments}

\subsubsection{Fourier Transformation Infrared (FTIR)}

Analyses were performed on a Varian spectrophotometer, 660-IR model, with a resolution of $4 \mathrm{~cm}-1$, comprising a spectral region covering the limits of $400 \mathrm{~cm}-1$ a $4000 \mathrm{~cm}-1$. The samples were prepared in $\mathrm{KBr}$ pellets. 


\subsubsection{Ultraviolet-visible (UV-vis)}

The UV-vis spectroscopy analyses were performed on a NIR Shimadzu equipment, UV3600 model, ranging from 185 to $800 \mathrm{~nm}$. The samples were prepared in pellets, which were prepared by a manual hydraulic press, brand: Specac.

\subsection{Procedures}

In a 3.6 L container $100 \mathrm{~g}$ of residual TLC silica gel was treated. It was added $500 \mathrm{~mL}$ of distilled water to initial wash. After addition of water, the mixture was left to stand for sedimentation for approximately 45 to 60 minutes. Then, the water was removed and the process was repeated three more times, using a total of 2 liters of distilled water. In the next step the silica was treated with $400 \mathrm{~mL}$ of sodium hypochlorite solution $(2.5 \% \mathrm{w} / \mathrm{w})$, which remained in the residual silica gel for 48 hours. At the end of this period, the excess of hypochlorite was removed and the material was washed 4 times with fractions of $500 \mathrm{~mL}$ of distilled water. After washing the recovered TLC silica gel was dried and activated in an oven at $100^{\circ} \mathrm{C}$ for 24 hours.

\section{Results and Discussion}

In order to prove the efficiency of the recovered silica gel, a TLC plate (Figure 1) was prepared for qualitative analysis of an alkylphenol purification process by column chromatography. With the aid of capillary tubes, aliquots were removed from the collected fractions of the column and then applied on chromatographic plates. After the visualization in iodine vapor, the TLC chromatographic plate prepared with recovered silica showed characteristics spots of the following compounds: alkylated cardanol and hydrogenated cardanol (Figure 2). In addition to the differential migration of the previously mentioned compounds, the chromatographic plate showed retention factors similar to the factors found for the TLC prepared with new silica gel. According to Degani et al. (1998) [17], the retention factor $\left(\mathrm{R}_{\mathrm{f}}\right)$ is the most important parameter related to TLC, defined as the ratio between the distance traveled by the analyte and the distance traveled by the mobile phase. 
Figure 1. Chromatoplate prepared with recovered silica gel 60G.

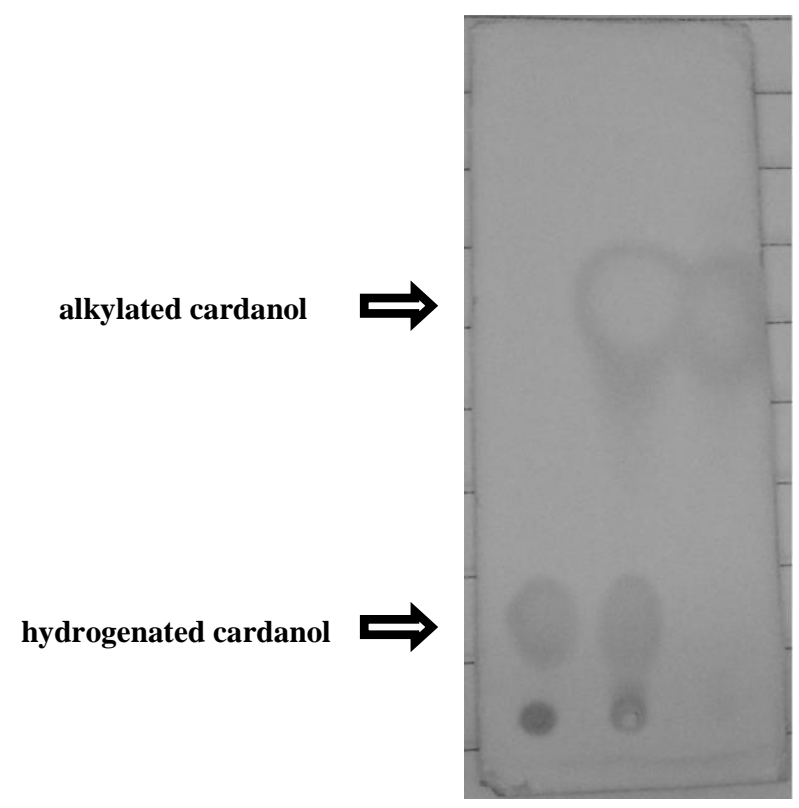

Reference: Author.

Figure 2. Chemical structures of hydrogenated cardanol and alkylated cardanol.

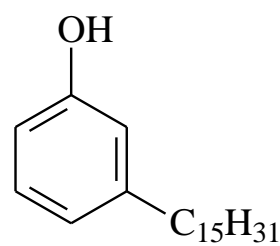

Hydrogenated cardanol<smiles>CCCCCCCCCCC(C)(C)c1ccc(C(C)(C)C)cc1O</smiles>

Alkylated cardanol

\section{Reference: Author.}

After knowing the alkylated cardanol and hydrogenated cardanol retention factors with the used elution conditions, other chromatographic plate with recovered silica gel was prepared using the same methodology, so that the efficiency and quality of the adsorbent recovery treatment could be proved. Thus, after elution, the region corresponding to the cardanol alkylated $R_{f}$ was shaved and the mixture silica+alkylated cardanol was "washed" with hexane solvent for extraction of alkylphenol.

In order to compare the chemical profiles of new and recovered silica gel, samples were prepared containing new TLC silica and recovered TLC silica. Figure 3 shows both the new TLC silica gel (new silica gel) and the recovered TLC silica gel (recovered silica gel) FTIR spectra. The spectra showed characteristic absorption bands for the new and recovered silica in which both exhibit significant intensities in the regions $469 \mathrm{~cm}^{-1}, 803 \mathrm{~cm}^{-1}, 966 \mathrm{~cm}^{-1}, 1091 \mathrm{~cm}^{-1}$ inherent to Si- 
$\mathrm{O}$ out of plane deformations, Si-O bending, $\mathrm{Si}-\mathrm{OH}$ stretching and $\mathrm{Si}-\mathrm{O}-\mathrm{Si}$ stretching, characteristic of the silica structure $[18,19]$. The band at $3431 \mathrm{~cm}^{-1}$ is attributed to Si-OH silica groups and the moisture adsorbed on $\mathrm{KBr}$ pellets [20,21].

Figure 3. FTIR spectra of new silica gel and recovered silica gel.

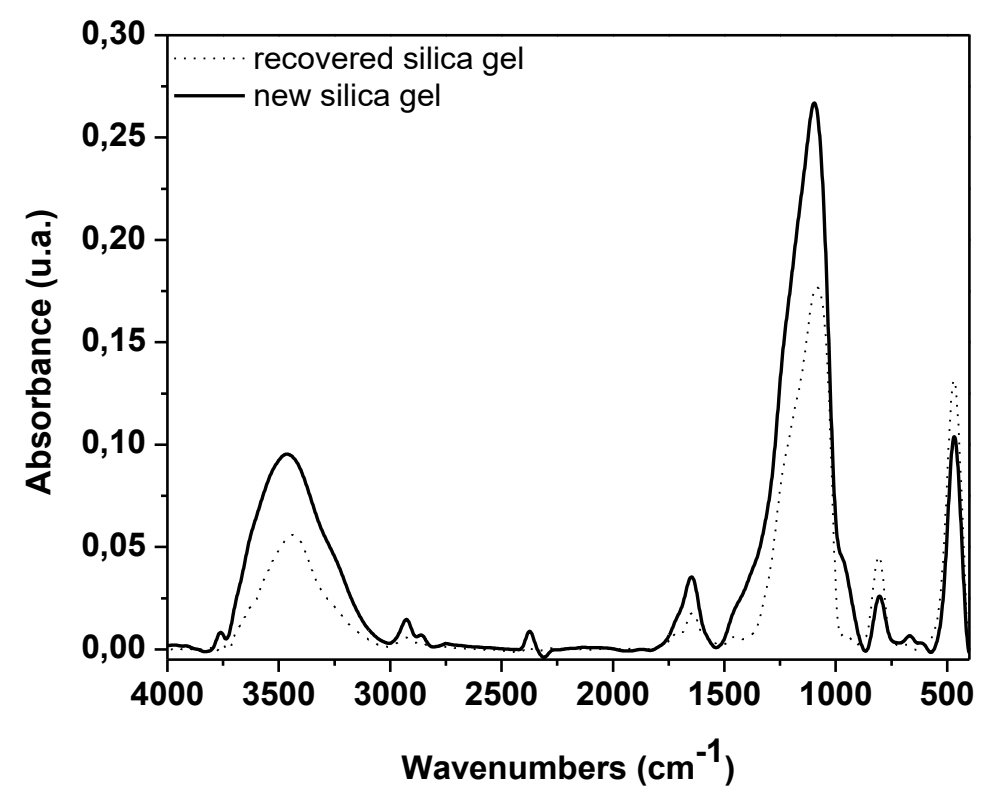

Reference: Author.

The spectra displayed in Figure 3 show similar chemical profiles for both silicas, proving that the treatment to which the residual silica went through did not cause chemical changes in the structure of the TLC silica gel, since the wavelengths relative to the bands of this material were not modified. To compare the adsorption potential of new and recovered silica samples of alkylated cardanol adsorbed on new and recovered silica were prepared such as samples of alkylated cardanol itself for analyzes in the infrared region. The vibrational modes of alkylphenols, Figure 4, presents molecular vibration bands at $1260-1000 \mathrm{~cm}^{-1}$, characteristics of CO links of phenolic compounds, as well as peaks related to molecular vibrations of $\mathrm{C}=\mathrm{C}$ links of aromatic rings at $1613-1572 \mathrm{~cm}^{-1}$, symmetrical and asymmetrical C-H molecular vibrations at $2848-2938 \mathrm{~cm}^{-1}$ and $\mathrm{OH}$ vibrations in the region of $3520 \mathrm{~cm}^{-1}[22,23,24]$. 
Figure 4. FTIR spectra of adsorbed new silica, adsorbed recovered silica gel and alkylated cardanol.

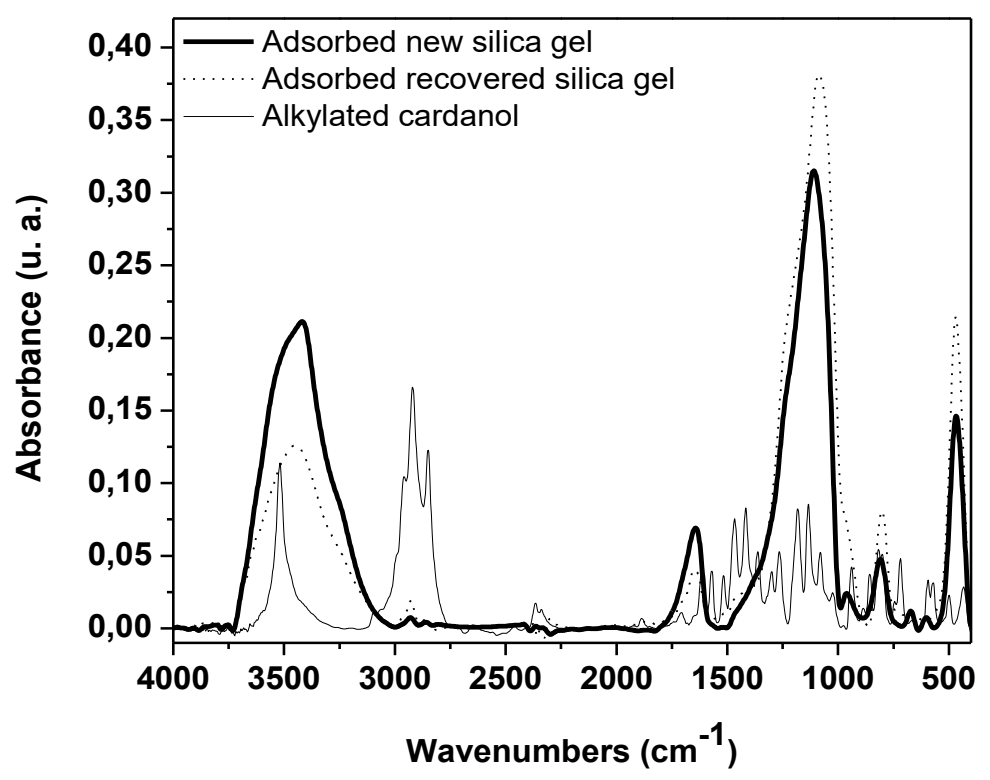

Reference: Author.

The analysis results also indicate that for the silica containing adsorbed alkylated cardanol there is a significant influence on the intensity of the vibration molecular peaks located in the region of $3520 \mathrm{~cm}^{-1}, 2848 \mathrm{~cm}^{-1}, 2938 \mathrm{~cm}^{-1}, 2357 \mathrm{~cm}^{-1}, 1091 \mathrm{~cm}^{-1}$ and $469 \mathrm{~cm}^{-1}$, as previously described [25]. This phenomenon is observed with greater intensity in the new adsorbed silica, probably due to its greater adsorption potential. Furthermore, the spectrum of adsorbed recovered silica gel is similar to the spectrum of adsorbed new silica gel, showing once again that the proposed treatment did not affect the adsorbent characteristics of the material.

Characterizations were carried out at Ultraviolet-visible (UV-visible) region to verify the efficiency of the adsorption of alkylated cardanol on the surface of recovered silica gel, taking the adsorbed new silica gel spectrum as a parameter. The samples included: new TLC silica (new silica gel), adsorbed new TLC silica (adsorbed new silica gel), recovered TLC silica (recovered silica gel), adsorbed recovered TLC silica (adsorbed recovered silica gel) and alkylated cardanol. In Figure 5, the spectra for the new silica and recovered silica shows that both have similar absorption profiles, besides that there is no absorption maximum originated from residual organic matter [26]. This fact confirms that the treatment carried out degraded the organic matter adsorbed on the residual silica. 
Figure 5. Absorbance spectra of new silica gel and recovered silica gel.

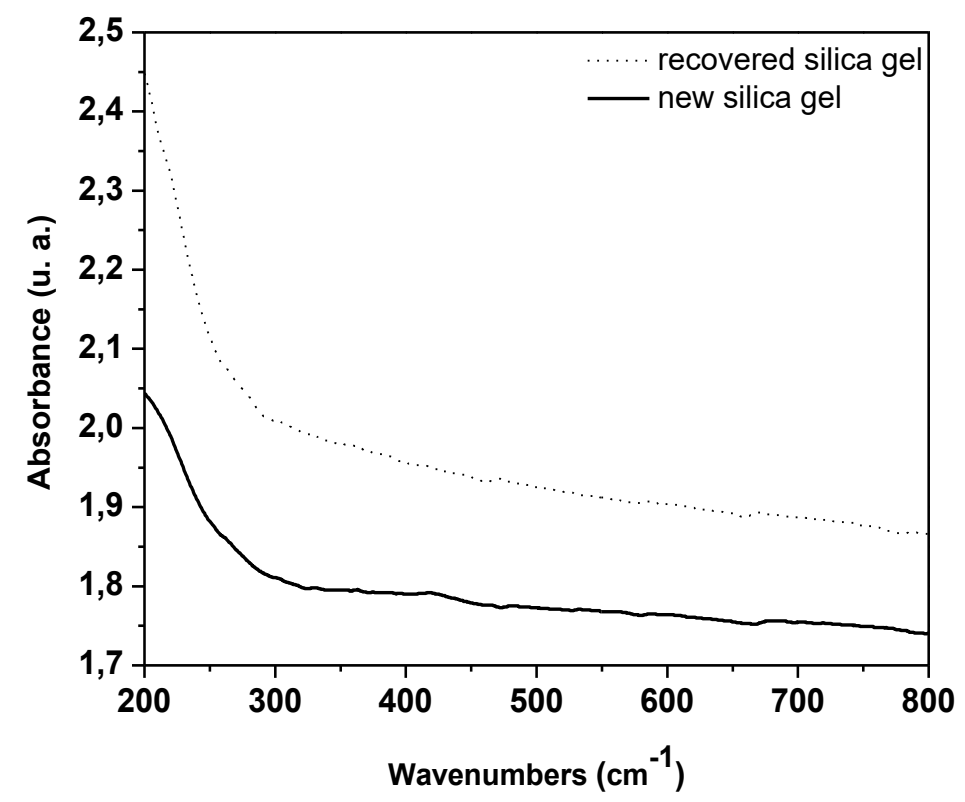

Reference: Author.

In the adsorbed new silica gel and adsorbed recovered silica gel spectra, Figure 6, it was detected an absorption maxima characteristic of the organic compound (alkylated cardanol) used for adsorption, showing a decrease of $16 \mathrm{~nm}$ when it is incorporated to the silica surface. This phenomenon may be caused by the energy gain from the matrix formed by the adsorbent. When the matrix receives energy in the form of ultraviolet radiation it can transfer electrons to the alkylated cardanol chain. The alkylphenol has an aromatic ring in its chemical structure with a carbon chain side attached to the meta position. The ring presents conjugations in its structure, which describe specific electronic transitions at $218 \mathrm{~nm}$ responsible for the transitions $\pi-\pi *$ of the $\mathrm{K}$ band of the aromatic ring, as well as, at $290 \mathrm{~nm}$ derived from the B band of aromatic ring, which can be observed in the spectrum below (Figure 6). Besides that, there is a absorption maximum at $422 \mathrm{~nm}$, characteristic of the yellowish color inherent to the organic compound. 
Figure 6. Absorbance spectra of adsorbed new silica gel, adsorbed recovered silica gel and alkylated cardanol.

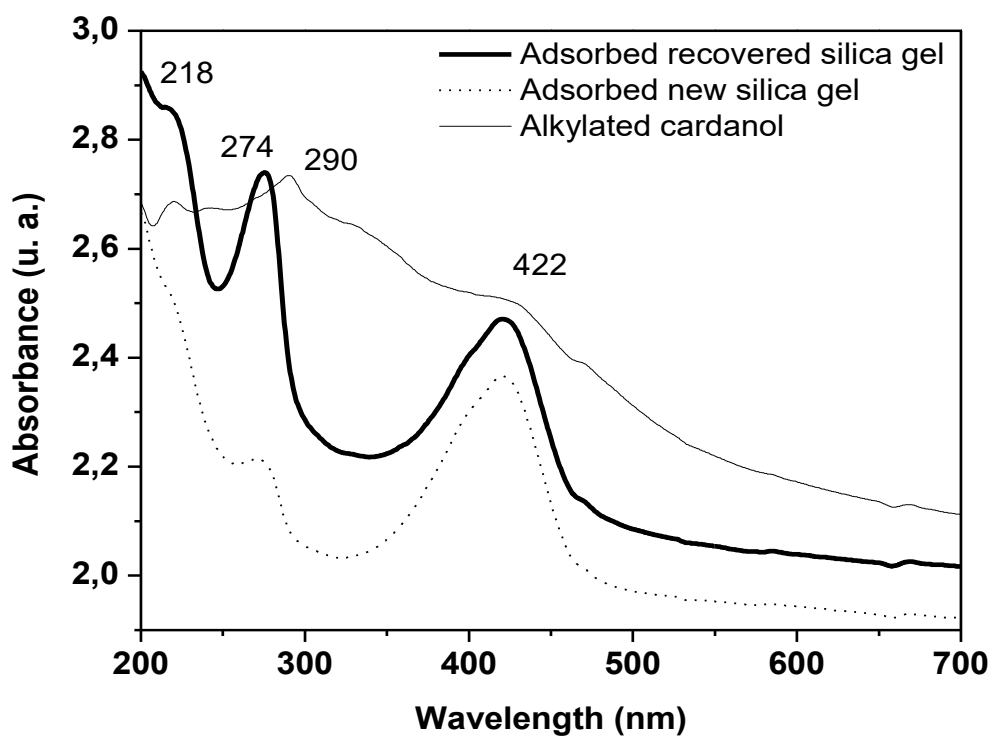

Reference: Author.

\section{Conclusion}

The recovered silica gel $60 \mathrm{G}$ using sodium hypochlorite $(2.5 \%, \mathrm{w} / \mathrm{w})$ is effective in the qualitative analysis of the cardanol alkylated purification process. The FTIR and UV-visible analyses confirmed that the applied treatment did not affect the characteristics of the material, since even when adsorbed with alkylphenol it presented chemical profile similar to the profile of a new adsorbed silica gel 60G.

It can be inferred that the proposed methodology was able to recover the residual silica gel, making it possible to be reused in the process of separation and/or purification of organic substances in a practical manner and with reduced environmental impact. The recovery procedure comprised an economically viable method that focuses on environmentally friendly disposal of residual silica gel by reusing it without compromising its effectiveness as an adsorbent. Moreover, it was possible to meet the principles of Green Chemistry regarding the reduction of solid waste generation, withdrawing a chemical residue impregnated with organic material, likely to contaminate the environment and hence the recovery of this material provided an economic gain in terms of reduction in the acquisition of this material.

\section{References}


RODRIGUES, G.D, SILVA, L.H.M AND SILVA, M.C.H, Alternativas verdes para o preparo de amostra e determinação de poluentes fenólicos em água. Química Nova, v. 33, n. 6, p. 1370-1378, 2010.

ANASTAS, P. AND EGHBALI, N. Green Chemistry: Principles and Practice. Chemical Society Reviews, v. 39, p. 301-312, 2010.

ANASTAS, P., Twenty years of green chemistry. Chemical \& Engineering News, v. 89, n. 26, p. 62-65, 2011.

AHLUWALIA, V.K AND KIDWAI, M., New Trends in Green Chemistry. Anamaya Publishers, New Delhi, India, p. 267, 2004.

SHELDON, R.A., Green solvents for sustainable organic synthesis: state of the art. Green Chemistry, v. 7, p. 267-278, 2005.

RAVICHANDRAN, S., Green Chemistry - A Potential tool for Chemical Synthesis. International Journal of Chem Tech Research, v. 2, n. 4, p. 2188-2191, 2010.

RAVICHANDRAN, S., Implementation of Green Chemistry Principles into Practice. International Journal of Chem Tech Research, v. 3, n. 3, p. 1046- 1049, 2011.

RAVICHANDRAN, S., Innovation in Green Chemistry. International Journal of Chem Tech Research, v. 3, n. 3, p. 1511-1513, 2011.

RAVICHANDRAN, S., Perspective and Fate of Green Chemistry. International Journal of Chem Tech Research, v. 3, n. 4, p. 1882-1885, 2011.

TEXEIRA, S.C.G, MATHIAS, L. AND CANELA, M.C., Recuperação de sílica-gel utilizando processos oxidativos avançados: uma alternativa simples e de baixo custo. Química Nova, v. 26, n. 6, p. 931-933, 2003.

COLLINS, C.H., BRAGA, G.L. AND BONATO, O.S., Introdução a Métodos Cromatográficos. 7th ed. Campinas; 1997.

SOUSA K.S, FILHA, V.L.S.A., PINTO, V.H.A, FONSECA, M.G., ESPÍNOLA, J.P.G. AND ARAKAKI, L.N., Quimissorção de Cátions Divalentes em Sílica Gel Modificada com Ácido Tioglicólico - A Influência do pH e Força Iônica. Química Nova, v. 30, n. 3, p. 528-534, 2007.

PRADO, A.G.S., FARIA, E.A., Aplicação e Modificação Química da Sílica Gel Obtida de Areia. Química Nova, v. 28, n.3, p. 544-547, 2005.

ANDREÃO, P.S.S, GIACOMINI, R.A., STUMBO, A.M., WALDMAN, W.R., BRAZ-FILHO, R., LIGIÉRO, C.B.P. AND MIRANDA, P.C.M.L., Utilização e recuperação de sílica gel impregnada com nitrato de prata. Química Nova,v. 33, n. 1, p. 212-215, 2010.

RIEHL, C.A.S. AND PINTO, A.C., Sílica-Gel: Uma Alternativa. Química Nova, v. 11, n. 3, p. 329-330, 1988.

LOUREIRO, A.P., SOUZA, J.A., APARECIDO, D. AND FERNANDES, J.B., Recuperação de Sílica Gel: Nova Alternativa. Química Nova, v. 14, n. 2, 112, 1991. 
DEGANI, A.L.G., CASS, Q.B., VIEIRA, P.C., Cromatografia um breve ensaio. Química Nova na Escola, v. 7, p. 21-25, 1998.

KNIPPING, J., WIGGERS, H., RELLINGHAUS, B., ROTH, P., KONJHODZIC, D. AND MEIER, C., Synthesis of High Purity Silicon Nanoparticles in a Low Pressure Microwave Reactor. Journal of Nanoscience and Nanotechnology, v. 4, n. 8, p. 1039-1044, 2004.

WIGGERS, H., STARKE, R. AND ROTH, P., Silicon Particle Formation by Pyrolysis of Silane in a Hot Wall. Chemical Engineering \& Technology, v. 24, n. 3, p. 261-264, 2001.

MATTOS, E.C., ITAMAR, V., LAZZARINI, D.R.C., FARIA, D.M. AND KOSHUN, I., Aplicação de Metodologias FTIR de Transmissão e Fotoacústica à Caracterização de Materiais Altamente Energéticos - Parte II. Química Nova, v. 25, n. 5, p. 722-728, 2002.

FILHO, E.C.S., FORTES, A.W.M., REIS, L.S., SANTOS, M.R.M.C, JÚNIOR, L.S.S. AND FONSECA, M.G., Sorção de chumbo numa sílica modificada obtida da crisotila: aplicação de isotermas. Comunicata Scientiae, v. 1, n. 1, p. 15-21, 2010.

BEGANSKIENE, A., SIRUTKAITIS, V., KURTINAITIENE, M., JUSKENAS, R. AND KAREIVA, A. FTIR, TEM and NMR Investigations of Stöber Silica Nanoparticles. Materials Science (Medžiagotyra), v. 10, n. 4, p. 287-290, 2004.

SILVERSTEIN, R.M., WEBSTER, F.X. AND KIEMLE, D.J., Spectrometric Identification of Organic Compounds. 7th ed. New York: John Wiley \& Sons, Inc, 2005. p. 550.

KOCIJAN, A., CONRADI, M. AND ZORKO, M., Surface Modification of Nanosilica Fillers for the Preparation of Silica/Epoxy Nanocomposites. Materials and Technology, v. 46, n. 6, p. 657659, 2012.

RISFAHERI, IRAWADI, T.T., NUR, M.A. AND SAILAH, I., Isolation of Cardanol from Cashew Nut Shell Liquid Using the Vacuum Distillation Method. Indonesian Journal of Agricultural Science, v. 2, n. 1, p. 11-20, 2009.

XAVIER, L.F.W., MOREIRA, I.M.N.S., HIGARASHI, M.M., MOREIRA, J.C., FERREIRA, L.F.V. AND OLIVEIRA, A.S., Fotodegradação de hidrocarbonetos policíclicos aromáticos em placas de sílica impregnadas com dióxido de titânio. Química Nova, v. 28, n. 3, p. 409-413, 2005.

Recebido: 29/06/2015

Aprovado: 06/06/2017 